\title{
Rafał Zgorzelski, Irena Przybysz, ks. Damian Klimkowski, Janina Fetlińska. Pielęgniarka, społecznik, senator RP 1952-2010, wyd. „Wspólnota Żyrardowa", Żyrardów 2019, ss. 255 (rec. Agnieszka Kozińska)
}

Janina Fetlińska. Pielęgniarka, społecznik, senator RP 1952-2010 to pierwsza publikacja o tej niezwykłej kobiecie, która „wszędzie gdzie się pojawiała, zostawiała trwały, niezapomniany, niezatarty ślad”, jak napisał w Słowie wstępnym Maciej Małecki.

Publikacja ma za zadanie przybliżyć i upamiętnić postać zmarłej tragicznie w katastrofie smoleńskiej 10 kwietnia 2010 r. Senator Fetlińskiej. Jest to owoc pracy zespołu autorów: Rafała Zgorzelskiego, Ireny Przybysz i ks. Damiana Klimkowskiego, którym udało się zebrać bogaty materiał dotyczący jej życia i działalności. W prace nad książką włączyli się też najbliżsi - mąż Włodzimierz Fetliński i syn Bartosz, którym autorzy dedykują tę książkę.

Została wydana przez Stowarzyszenie „Wspólnota Żyrardowa” w 2019 r., lecz nie jest przeznaczona do regularnej sprzedaży (można ją było otrzymać m.in. na spotkaniach promocyjnych), co niestety ogranicza dostęp szerszego odbiorcy.

W części Od autorów zawarte są informacje o katastrofie smoleńskiej, jej ofiarach, a szczególnie o Janinie Fetlińskiej, która „zapisała się w pamięci swoich bliskich i współpracowników jako osoba wyrazista, silnie oddziaływająca na rodzinę, przyjaciół i znajomych, a także na społeczność Ciechanowa i ziemi ciechanowskiej. Oddana ważnym sprawom Ojczyzny i Kościoła, ale przede wszystkim zwykłych ludzi”.

Książka liczy 255 stron, ma bogatą szatę graficzną, zawiera ponad 150 zdjęć w różnym formacie (zarówno czarno-białe, jak i kolorowe), co zapewnia łatwość odbioru treści. Składa się z 6 rozdziałów: I. Strony ojczyste i rodzina, II. Pierwsze kroki w pielegniarstwie, III. Aktywność zawodowa i praca naukowa, IV. Społecznik, polityk, senator $R P$, V. Matżeństwo, rodzina, dom... czyli Janina Fetlińska prywatnie, VI. Ostatnia pielgrzymka. 
Publikację wzbogaca Aneks, który zawiera: wykaz odznaczeń, nagród, nadanych tytułów, kalendarium aktywności zawodowej, bibliografię najważniejszych artykułów i opracowań jej autorstwa, homilię biskupa płockiego i mowę pogrzebową S. Karczewskiego. Zamieszczono też bibliografię publikacji źródeł, z których korzystali autorzy.

Rozdział I - Strony ojczyste i rodzina - jest opisem szczęśliwego dzieciństwa w niewielkiej wsi Tuligłowy, gdzie dorastała (wraz z dwiema siostrami) w domu pełnym miłości, kultywującym tradycje obchodzenia świąt czy świętowania uroczystości rodzinnych. „Oboje rodzice byli ludźmi głębokiej wiary, honorowi i gościnni” - mówiła o nich Zofia, siostra Janiny. Z domu rodzinnego wyniosła miłość do książek, zamiłowanie do turystyki (rajdy po Bieszczadach), miłość do przyrody, przywiązanie do wiary i Kościoła, szacunek do pracy i zasadę niemarnowania wolnego czasu. Ta pracowita codzienność, kochająca się rodzina, ciepło rodzinnego domu ukształtowały charakter Janiny Fetlińskiej. Jej spokój, pogoda ducha, głęboka wiara, patriotyzm, ciekawość świata i ludzi to cechy płynące ,z jej poczucia zakorzenienia w tuligłowskiej ziemi, w rodzinie głębokiej wiary i patriotycznych tradycji” - jak podkreślała Zofia Galicka. Ponadto dodaje, że Janina „po rodzicach odziedziczyła inteligencję i bystrość umysłu”. W dalszej części książki czytelnik przekona się, jak wielkie znaczenie miało moralne dziedzictwo wyniesione $\mathrm{z}$ domu w dorosłym życiu i działalności Janiny Fetlińskiej.

Pierwsze kroki w pielęgniarstwie to II rozdział, z którego dowiadujemy się, jak przebiegała ścieżka naukowa i zawodowa przyszłej doktor nauk medycznych (pierwszej w Polsce) w zakresie pielęgniarstwa. Autorzy podkreślają, że była niesamowicie zdolna i pracowita, o czym świadczą bardzo dobre oceny na świadectwach i dyplomy naukowe z wyróżnieniem. Oprócz nauki i pracy Janina Fetlińska cały czas zajmowała się działalnością społeczną. Aktywną postawą społeczną wykazała się już w czasie studiów, działając w Studenckim Towarzystwie Naukowym Uczelnianej Komisji Nauki czy Komisji Nauki społeczności akademika. W czasie pracy w szpitalu w Ciechanowie była początkowo młodszym asystentem do spraw szkolenia personelu średniego, potem kierownikiem Wojewódzkiego Ośrodka Kadr Medycznych. Zajmowała się organizowaniem oraz prowadzeniem kształcenia pielęgniarek z woj. ciechanowskiego, organizowała nowatorskie formy kształcenia pielęgniarek środowiskowych, lekarzy POZ i pracowników socjalnych. Przygotowywała olimpiady pielęgniarskie i położnicze dla szkół medycznych. Po uzyskaniu tytułu magistra pie- 
lęgniarstwa medycyny społecznej w latach 1980-1984 była wizytatorką średnich szkół medycznych w Ciechanowie i Działdowie. Będąc na urlopie wychowawczym, zrobiła specjalizację II stopnia w zakresie organizacji ochrony zdrowia (1984) i zajmowała się pisaniem doktoratu pod kier. dr. hab. n. med. Marka Saneckiego, a pracę obroniła 26 listopada 1986 r., otrzymując stopień dr. n. med. w zakresie pielęgniarstwa. „Przez miłość do ludzi zostałam pielęgniarką, przez miłość do nauki po krakowskim liceum medycznym podjęłam studia pielęgniarskie, wówczas jeszcze jedyne w Polsce, na Akademii Medycznej w Lublinie. Wszystko, co dobre i piękne można było przekazać młodemu człowiekowi - łącznie z wiedzą medyczną - tam zostało mi przekazane i wzmocnione”. Te słowa Janiny Fetlińskiej uzasadniają zarówno wybór zawodu, jak i ciągłe kształcenie się. Już jako senator RP mówiła do dzieci i młodzieży szkolnej: „Widzicie, jestem z małej wioski. Wy też wierzcie $\mathrm{w}$ to, że każde $\mathrm{z}$ was może w życiu dużo osiągnąć”. Właśnie ona była przykładem na to, że dzięki sile charakteru i pracowitości można spełnić swoje marzenia. W pracy zawodowej „wykazywała się wielką energią, pracowitością i ambitnym konsekwentnym działaniem”. Jak ogromna była jej aktywność zawodowa, wskazuje Kalendarium aktywności zawodowej.

III rozdział książki -Aktywność zawodowa i praca naukowa-zwraca uwagę czytelnika na ogromne zaangażowanie Janiny Fetlińskiej w prace na rzecz rozwoju pielęgniarstwa, szczególnie w Ciechanowie, a także podnoszenia kwalifikacji zawodowych pielęgniarek. Lata 90. to czas niezwykle dynamicznego rozwoju kariery zawodowej Janiny Fetlińskiej. Największe osiągnięcia to utworzenie Mazowieckiego Centrum Zdrowia Publicznego, starania o otwarcie w Ciechanowie Państwowej Wyższej Szkoły Zawodowej, uwieńczone sukcesem w 2001 r., zorganizowanie oddziału Głównej Biblioteki Lekarskiej w Ciechanowie. W ramach nowo powstałej uczelni utworzono Instytut Ochrony Zdrowia z kierunkiem pielęgniarstwo, którego w 2002 r. Janina Fetlińska została dyrektorem. Przygotowywała wraz z zespołami różne projekty z dziedziny ochrony zdrowia, zawsze z sukcesem. W $1991 \mathrm{r}$. jej zespół wygrał konkurs Ministerstwa Zdrowia i Opieki Społecznej oraz Banku Światowego na utworzenie eksperymentalnego konsorcjum zdrowia w ramach projektu pt. „Reformy polskiej służby zdrowia”. W latach 1994-1998 pełniła funkcję dyrektora Biura Ciechanowskiego Konsorcjum Zdrowia, co otworzyło przed nią szerokie możliwości badawcze i naukowe. Odbyła podróże zagraniczne m.in. do USA i Kanady, by zapoznać się z pracą amerykańskich pielęgniarek. Brała udział 
jako członek w zespole przygotowującym pierwszą wersję reformy podstawowej opieki zdrowotnej, opartej o system lekarza rodzinnego. Tworzyła pielęgniarstwo rodzinne od podstaw. W dyskusjach, konferencjach, seminariach uczestniczyła jako ekspert. W Ciechanowskim Konsorcjum Zdrowia przygotowała i wdrożyła wraz z zespołem liczne programy z zakresu profilaktyki chorób i promocji zdrowia. Janina Fetlińska była też wykładowcą w PWSZ w Ciechanowie, a także prowadziła seminaria licencjackie i magisterskie. W czasie działalności naukowej współpracowała z uniwersytetami w Lublinie, Wrocławiu, Białymstoku. Pisała rozprawę habilitacyjną pod kierunkiem prof. Bożeny Urbanek w IHN PAN, której nie zdążyła ukończyć.

W rozdziale IV pt. Społecznik, polityk $i$ senator RP autorzy podejmują próbę pokazania aktywności społecznej bohaterki publikacji i jej służby dla RP. W latach 90. zdecydowała się na działalność polityczną, począwszy od pełnienia funkcji radnej powiatu ciechanowskiego, po wygraną w wyborach do Senatu RP w 2005 r. i powtórnie w 2007 r. Zawsze podkreślała, że jest przede wszystkim pielęgniarką i właśnie dla tego środowiska zrobiła najwięcej. „Mój zawód - pielęgniarstwo - nauczył mnie patrzeć na drugiego człowieka jak na osobę, której zawsze powinnam udzielić pomocy $\mathrm{w}$ potrzebie. Moja wewnętrzna społecznikowska pasja powoduje, że zawsze staram się widzieć grupy społeczne i społeczności, dla których mogę być użyteczna” - tak pisała w podziękowaniu wyborcom jako senator. Interesowały ją sprawy Polonii, angażowała się w działalność poza granicami ojczyzny. Wszyscy, nawet oponenci, cenili Panią Senator za jej pracowitość, profesjonalizm, odwagę i kulturę osobistą. Ona także szanowała nawet konkurentów politycznych. Przyglądając się pracy Pani Senator i jej nieustannym działaniom, Maciej Małecki - współpracownik, poseł, powiedział: „Zastanawiam się zawsze, wiedząc dziś jak wygląda praca parlamentarzysty, w jaki sposób znajdowała na to wszystko czas”. Podobne pytanie może stawiać sobie czytelnik, poznając ogrom przykładów działalności i dokonań Janiny Fetlińskiej na gruncie zawodowym, społecznym i politycznym. Ona sama nie uważała tego, co robi, za coś nadzwyczajnego. Mówiła: „,...] zawsze lubiłam pracować i zawsze łączyłam w swoim życiu wiele funkcji, nigdy nie byłam monotematyczna. [...] Podejmowałam się rzeczy bardzo trudnych i w odczuciu niektórych - niemożliwych. Zdobywałam je długo, uparcie, ale ostatecznie z dobrym skutkiem". Przy ogromnych zasługach Janina Fetlińska pozostała osobą bardzo skromną. Nie lubiła niepotrzebnego rozgłosu wokół własnej osoby. Wielokrotnie odrzucała propozycje 
odznaczeń i nagród, mówiąc, że nie jest to potrzebne, gdy „żyje się ideałami i pracuje dla swojego narodu".

Kolejny, V rozdział Małżeństwo, rodzina, dom... czyli Janina Fetlińska prywatnie poświęcony jest życiu osobistemu Pani Senator. Z mężem Włodzimierzem poznali się na studiach $\mathrm{w}$ Lublinie w 1974 r., po ślubie zamieszkali w Ciechanowie - rodzinnym mieście Włodzimierza. Szczęśliwe małżeństwo przetrwało 33 lata, aż do tragicznej śmierci Janiny. We wspomnieniach męża, ukochanego syna Bartosza, rodziny i przyjaciół pozostaje jako osoba pełna głębokiej wiary, ciepła, gościnna („Mnóstwo ludzi przewinęło się przez nasz dom - wspominał mąż”), pogodna, wrażliwa, a przede wszystkim bardzo pracowita, nieznosząca marnowania czasu. Wolne chwile wykorzystywała na czytanie książek, spacery, wyjścia do teatru czy spotkania z przyjaciółmi. Fetlińscy często korzystali z zaproszeń i uczestniczyli $\mathrm{w}$ imprezach i uroczystościach związanych z pracą czy działalnością społeczną Janiny.

W pamięci tych, którzy ją znali, pozostała jako osoba elegancka, bezpośrednia w kontaktach, pozytywnie nastawiona do świata i ludzi. Jej siostra Zofia wspominała, że Janina tylko z pozoru „sprawiała wrażenie kruchej, słabej kobiety”. W rzeczywistości „była bardzo silną i wyrazistą osobowością, miała charyzmę, to, co niełatwo wyrazić słowami”. W opinii współpracowników była wymagająca. „Od siebie wymagała nade wszystko, ale i wymagała od innych” - wspominała dr Małgorzata Marcysiak z PWSZ w Ciechanowie. „Pielęgniarstwo było jej ukochanym dzieckiem. To naprawdę było jej powołanie i misja. Była ona naszym wieloletnim dyrektorem i menedżerem - najwspanialszym, jakiego mogłyśmy sobie wyobrazić" - to wspomnienia koleżanek.

Końcowy rozdział publikacji - Ostatnia pielgrzymka - opisuje okoliczności wyjazdu Janiny Fetlińskiej do Smoleńska, tragicznej śmierci, uroczystości pogrzebowe oraz akty upamiętnienia osoby Pani Senator. Ogrom pracy Janiny Fetlińskiej - zawodowej, społecznej, politycznej widoczny jest w Kalendarium... czy Bibliografii opracowań artykułów dr Janiny Fetlińskiej (wybór). To są te najważniejsze dokonania.

$\mathrm{Z}$ okładki książki spogląda młodziutka, uśmiechnięta pielęgniarka. Ten uśmiech i radość zachowała przez całe życie, co podkreślali we wspomnieniach wszyscy ci, którzy ją znali.

Publikacja jest niezwykle ciekawa, bo jej bohaterka to postać wyjątkowa. Autorzy zebrali ogromną ilość materiału fotograficznego, rozmów, wspomnień. Zdjęcia zamieszczone w publikacji pochodzą 
z archiwum rodzinnego Fetlińskich, z archiwów przyjaciół i współpracowników.

Na pewno każdy z czytelników odnajdzie na kartach tej publikacji Wspaniałego Człowieka - spełniając nadzieję jej autorów. „Książka będzie wyrazem dopełnienia jej dobroci, szlachetności, zaangażowania się w to, żeby pomóc" - napisała Zofia Połatyńska, emerytowana pielęgniarka.

W książce odnajdziemy zabawne anegdoty związane z Panią Senator. Dla pielęgniarek - Janeczka, dla przyjaciół Inka.

Gdy czyta się o dokonaniach jednego człowieka na wielu płaszczyznach działalności, zastanawiać się można, jak to możliwe, że w tej niepozornej kobiecie skupiło się tyle siły, determinacji, miłości do ludzi, wrażliwości, talentu i energii, by zostawić po sobie ten ogromny dorobek. Całe życie walczyła, by zawód pielęgniarki był doceniany, a pielęgniarki były dumne, że go wykonują. 